\title{
Improvement of methodology for accounting of extra-budgetary resources of public educational and medical institutions
}

\author{
Azamat Ostonokulov \\ Tashkent Institute of Finance, Tashkent, Uzbekistan
}

\begin{abstract}
In the context of the pandemic, it is more relevant than ever to increase the expenditure of the state budget and the effective use of funds to ensure the openness and transparency of financial information about budget execution. This research investigates the sources of formation and direction of spending of extra-budgetary resources of public educational and medical institutions and the need to form systematic information about their movement from a scientific and theoretical standpoint. An analysis of the current state of accounting for extra-budgetary resources of public educational and medical institutions was carried out. Scientific proposals and practical recommendations for the effective management of extrabudgetary resources of educational and medical institutions and the improvement of their accounting methodology according to international accounting standards in the public sector have been developed.
\end{abstract}

\section{Introduction}

The private sector and the public sector are very important in the development of the country's economy and ensure the well-being of the population. In addition to performing the functions of the Government to society and delivering services, stimulating, regulating and controlling the economy, and providing employment, the public sector carries out a number of noncommercial activities, such as the provision of educational and medical services by the State. In turn, financing the activity of the public sector in these areas is carried out through the formation of the state budget. Public education and health institutions are among the most important areas of the public sector, including $66.8 \%$ of public sector institutions and allocating $52.1 \%$ of the State budget expenditures. [1]

As was pointed out by the President of Uzbekistan, serious steps have been taken to implement market mechanisms in all sectors of our economy over the past four years. The current task is to create the foundation for long-term sustainable growth through deep structural reforms [2]. One of the important tasks is to realize several reforms to reduce the tax burden and increase the financing of public sector institutions from extra-budgetary sources, taking into account the requirements of the market economy while maintaining the social orientation of state budget expenditures. This, in turn, requires comprehensive research to ensure targeted use of budget and extra-budgetary funding of public educational and medical institutions and transparency and reliability of information about spending of resources. 
Based on the functioning of the information system for the management of public finances and the possibilities of using the information system of accounting in budget organizations, it is necessary to conduct researches to improve the formation and management of extrabudgetary resources in public educational and medical institutions, as well as the methodology for accounting of income and costs by the sources of their formation.

\section{Materials and Methods}

The research uses scientific methods of learning the processes of economic reality, such as observation, sampling, generalization, grouping, comparison, logical and comparative methods of analysis, induction and deduction, systemic analysis of the socio-economic phenomenon, abstract and logical thinking, comparative analysis, perspective prediction, monographic observation and other methods.

\section{Results}

Public educational and medical institutions, along with funding from the state budget by a legislative budget base, are also financed by the Fund for development of the budget organization, by the Fund for material incentives and the development of medical facilities, by forming extra-budgetary resources through payments levied on budget organizations. In turn, if we study the structure of these sources of financing, they are divided into followings:

1) Income of the Fund for the development of budget organization is formed through:

Resources, which are saved on the cost estimates at the end of the last business day of the reporting quarter (excluding resources to capital investments financing);

Income from the sale of goods (works, services) according to activity profile;

Part of the resources received from the rental of assets, which included on the balance sheet of the budget organization;

Resources left in accordance with the established procedure at the disposal of budgetary organizations;

Resources received from charity.

2) Income of the Fund for material incentives and development of medical facilities is formed through:

Budget allocation - up to 5 per cent of the total volume of resources, which are allocated to the medical facility;

Income from the sale of goods (works, services) according to the activity profile;

Resources, which are saved on the cost estimates at the end of the last business day of the reporting quarter (excluding resources to capital investments financing);

Part of the resources received from the rental of assets, which included on the balance sheet of the budget organization;

Resources left in accordance with the established procedure at the disposal of budgetary organizations;

Resources received from charity.

3) Budgetary organizations form their extra-budgetary funds by fees charged

- for the maintenance of students and pupils in public preschool educational institutions, extended day groups in general education schools, boarding schools, specialized boarding schools of the Olympic reserve and other educational organizations;

- for training pupils in children`s music and arts schools and out-of-school institutions;

- for trainings in higher and secondary special, professional educational institutions;

- for the food supply of the contingent under treatment in inpatient medical and preventive institutions; 
- for other types of fee in accordance with the legislative base. [3]

Many legal instruments, which are regulated using and managing these resources by public educational and medical institutions, have been developed in Uzbekistan. In particular, Cabinet of Ministers Resolution No.414 On improving the procedure for budgetary financing organizations dated 3 September 1999 established the procedure for the formation of a fund for the development of a budgetary organization and the use of these resources. [4]

By Cabinet of Ministers Resolution No. 276 "On the approval of an improved wage system of medical workers" dated December 21, 2005, organization of the Fund for the material stimulation and development of medical organizations and the directions of expenditure of its funds were established.[5] Also, the Ordinance No.1537 "On the Fund for Material Incentives and Development of Medical Organizations" dated January 14, 2006, establishes the procedure for the formation and distribution of funds resources of medical organizations, the establishment of bonuses and incentives for employees of medical institutions, the expenditure of funds resources for the development of the material and technical base of institutions, modernization and repair.

The Ordinance No.2821 "On the procedure for the payment of fees for the maintenance of children in preschool institutions and boarding schools" dated August 23, 2016, established the procedure for the payment and calculation of fees for the maintenance of children in preschool educational institutions.[6] Based on Ordinance No.2431 "On the tuition fees of education in higher and secondary special and professional educational institutions and the procedure for spending the resources" dated February 26, 2013, it was established the procedure for agreeing to the fee-based form of education in higher and secondary special educational institutions, the amount of the fee, the procedure for distribution of received resources. [7] The Ordinance No.2634 "On the Procedure for the compilation, approval and registration of cost estimates and staffing tables of budget organizations and recipients of budget funds" dated December 15, 2014, establishes the procedure of the compilation, approval, consideration and registration of estimates of income and costs for extra-budgetary funds of institutions.

Based on the requirements of these legal instruments, public educational and medical institutions submit to financial administration estimates of income and costs from extrabudgetary funds, which are prepared independently and approved. At the same time, when planning expenditures for each extra-budgetary item, expenditures are planned based on the surplus of available funds at the beginning of the financial year and the expected amount of income from these funds. In accordance with the procedure established by the above legal instruments, extra-budgetary funds are spent for established purposes.

If we study the procedure established in the above legal acts, we can see some controversial situations related to managing extra-budgetary funds of institutions and ensuring their targeted use.

1. The analysis shows that the resources unspent at the current period, which are set for concrete purposes in the expenditure portion of the extra-budgetary estimates of organizations, are carried forward to the next financial year in the surplus form and, in turn, in the next financial year they are planned and spent under other items of expenditure. This situation impedes the provision of extra-budgetary funds in educational and medical institutions during the financial year for established purposes. Institutions may artificially suspend extra-budgetary funds for such purposes during the fiscal year and establish a basis for spending them in the next fiscal year for other purposes. Here is only one example: it is considered inappropriate to reduce or limit the planned costs of material incentives and the monthly issuance of bonuses to employees in the fiscal year from extra-budgetary funds by spending these funds in the next fiscal year on the development of physical infrastructure. 
2. Extra-budgetary resources of public educational and medical institutions are funds at the disposal of the institution, which must be managed in accordance with the legislative base and used for the intended purpose in cases provided in the estimates. In the activities of the institution during the financial year, these funds can create additional sources of funding that are not provided in the estimates. In our opinion, in the current conditions of a market economy, institutions should develop scientific and innovative cooperation, create new sources of extra-budgetary funds, and increase their volume. Therefore, it should be borne in mind that the costs incurred under the approved estimates can be increased relative to the approved volumes if possible to cover them from the expected revenues.

Revenues from extra-budgetary sources of public educational and medical institutions and ensuring their spending within the framework of the legislation are carried out through their accounting. Also, to generate current and consolidated information on the movement of extra-budgetary resources of public educational and medical institutions, accounting works are carried out directly in the institutions themselves, with separate records of income (revenues) and costs, as well as related receivables and payables.

In practice, the accounting of income (revenues) from extra-budgetary resources of public educational and medical institutions is carried out as follows (Table 1).

Table 1. Accounting of income from extra-budgetary funds in public educational and medical institutions [8].

\begin{tabular}{|c|c|c|c|}
\hline \multirow{2}{*}{ № } & \multirow{2}{*}{ Transaction content } & \multicolumn{2}{|c|}{ Accounting Entry } \\
\hline & & Debits & Credits \\
\hline \multicolumn{4}{|c|}{ Income of the Fund for development of budget organization } \\
\hline 1. & $\begin{array}{l}\text { Revenues of resources, which are saved on the cost } \\
\text { estimates at the end of the last business day of the } \\
\text { reporting quarter }\end{array}$ & $\begin{array}{l}\text { 112-"Resources of } \\
\text { Fund for development } \\
\text { of the budget } \\
\text { organization" }\end{array}$ & 232-"Budget Financing" \\
\hline 2. & $\begin{array}{l}\text { Income from the sale of goods (works, services) } \\
\text { according to the activity profile }\end{array}$ & $\begin{array}{l}\text { 200-“Sales of } \\
\text { products (works, } \\
\text { services)" }\end{array}$ & $\begin{array}{l}262-\text { "Income from } \\
\text { resources of Fund for } \\
\text { development of the } \\
\text { budget organization" }\end{array}$ \\
\hline 3. & $\begin{array}{l}\text { Part of the resources received from the rental of } \\
\text { assets, which included on the balance sheet of the } \\
\text { budget organization }\end{array}$ & $\begin{array}{l}\text { 159-"Settlements with } \\
\text { other debtors and } \\
\text { creditors" }\end{array}$ & $\begin{array}{l}262 \text {-"Income from } \\
\text { resources of Fund for } \\
\text { development of the } \\
\text { budget organization" }\end{array}$ \\
\hline 4. & Resources received from charity & $\begin{array}{l}\text { Relevant assets } \\
\text { accounts }\end{array}$ & $\begin{array}{l}\text { 262-“Income from } \\
\text { resources of Fund for } \\
\text { development of the } \\
\text { budget organization" }\end{array}$ \\
\hline \multicolumn{4}{|c|}{ Income of the Fund for material incentives and development of medical facilities } \\
\hline 1. & $\begin{array}{l}\text { Budget allocation - up to } 5 \text { percent of the total } \\
\text { volume of resources, which are allocated to the } \\
\text { medical facility }\end{array}$ & $\begin{array}{c}\text { 112-"Resources of } \\
\text { Fund for development } \\
\text { of the budget } \\
\text { organization" }\end{array}$ & 232-"Budget Financing" \\
\hline 2. & $\begin{array}{l}\text { Revenues of resources, which are saved on the cost } \\
\text { estimates at the end of the last business day of the } \\
\text { reporting quarter }\end{array}$ & $\begin{array}{l}\text { 112-"Resources of } \\
\text { Fund for development } \\
\text { of the budget } \\
\text { organization" }\end{array}$ & 232-"Budget Financing" \\
\hline 3. & $\begin{array}{l}\text { Income from the sale of goods (works, services) } \\
\text { according to the activity profile }\end{array}$ & $\begin{array}{l}\text { 200-"Sales of } \\
\text { products (works, } \\
\text { services)" }\end{array}$ & $\begin{array}{l}\text { 262-"Income from } \\
\text { resources of Fund for } \\
\text { development of the } \\
\text { budget organization" }\end{array}$ \\
\hline 4. & $\begin{array}{l}\text { Part of the resources received from the rental of } \\
\text { assets, which included on the balance sheet of the } \\
\text { budget organization }\end{array}$ & $\begin{array}{l}\text { 159-"Settlements with } \\
\text { other debtors and } \\
\text { creditors" }\end{array}$ & $\begin{array}{l}262 \text {-"Income from } \\
\text { resources of Fund for } \\
\text { development of the } \\
\text { budget organization" }\end{array}$ \\
\hline
\end{tabular}

Table 1. Continued. 


\begin{tabular}{|c|l|c|c|}
\hline 5. & Resources received from charity & $\begin{array}{c}\text { Relevant assets } \\
\text { accounts }\end{array}$ & $\begin{array}{c}\text { 262-"Income from } \\
\text { resources of Fund for } \\
\text { development of the } \\
\text { budget organization" }\end{array}$ \\
\hline \multicolumn{2}{|c|}{ Resources forming by charged fees at educational and medical institutions } \\
\hline 1. & $\begin{array}{l}\text { Fee for the maintenance of students and pupils in } \\
\text { public preschool educational institutions, extended } \\
\text { day groups in general education schools, boarding } \\
\text { schools, specialized boarding schools of the } \\
\text { Olympic reserve and other educational } \\
\text { organizations; }\end{array}$ & $\begin{array}{c}\text { 156-"Settlements for } \\
\text { special types of } \\
\text { charges" }\end{array}$ & $\begin{array}{c}\text { 242-"Parental resources } \\
\text { accrued to educational } \\
\text { institutions" }\end{array}$ \\
\hline 2. & $\begin{array}{l}\text { Fee for training in higher and secondary special, } \\
\text { professional educational institutions; }\end{array}$ & $\begin{array}{c}\text { 175-"Other } \\
\text { settlements with } \\
\text { students" }\end{array}$ & $\begin{array}{c}\text { 252-"Income from the } \\
\text { funds of paid-contract } \\
\text { training in educational } \\
\text { institutions" }\end{array}$ \\
\hline 3. & $\begin{array}{l}\text { Fee for the food supply of the contingent under } \\
\text { treatment in inpatient medical and preventive } \\
\text { institutions; }\end{array}$ & $\begin{array}{c}156 \text {-"Settlements for } \\
\text { special types of } \\
\text { charges" }\end{array}$ & $\begin{array}{c}\text { 242-"Parental resources } \\
\text { accrued to educational } \\
\text { institutions" }\end{array}$ \\
\hline
\end{tabular}

As we can see from the table, at all institutional revenues of resources, which are saved on the cost estimates at the end of the last business day of the reporting quarter, budget allocation up to 5 per cent of the total volume of resources, which are allocated to the medical facility and resources received from the charity are accounted as income in relation to their movement. In other cases, accounting of extra-budgetary income would create receivables and requires an accounting of their revenues to personal treasury accounts (table 2).

Table 2. Extra-budgetary revenues to treasury personal accounts of public educational and medical institutions [8].

\begin{tabular}{|c|c|c|c|}
\hline \multirow{2}{*}{ № } & \multirow{2}{*}{ Transaction content } & \multicolumn{2}{|c|}{ Accounting Entry } \\
\hline & & Debits & Credits \\
\hline \multicolumn{4}{|c|}{ Revenues of the Fund for development of budget organization resources } \\
\hline 1. & $\begin{array}{l}\text { Resources received from buyers for products } \\
\text { sold, works performed and services rendered }\end{array}$ & $\begin{array}{l}\text { 112-"Resources of } \\
\text { Fund for development } \\
\text { of the budget } \\
\text { organization" }\end{array}$ & $\begin{array}{l}\text { 152-"Settlements } \\
\text { with Buyers and } \\
\text { Customers" }\end{array}$ \\
\hline 2. & Rental revenues & $\begin{array}{l}112 \text {-"Resources of } \\
\text { Fund for development } \\
\text { of the budget } \\
\text { organization" }\end{array}$ & $\begin{array}{l}\text { 159-"Settlements } \\
\text { with other } \\
\text { debtors and } \\
\text { creditors" }\end{array}$ \\
\hline \multicolumn{4}{|c|}{ Revenues of resources forming by charged fees at educational and medical institutions } \\
\hline 1. & $\begin{array}{l}\text { Revenues from fee for the maintenance of } \\
\text { students and pupils in public preschool } \\
\text { educational institutions, extended day groups in } \\
\text { general education schools, boarding schools, } \\
\text { specialized boarding schools of the Olympic } \\
\text { reserve and other educational organizations }\end{array}$ & $\begin{array}{l}110 \text {-“Resources } \\
\text { received from special } \\
\text { types of payment" }\end{array}$ & $\begin{array}{l}\text { 156-"Settlements } \\
\text { for special types } \\
\text { of charges" }\end{array}$ \\
\hline 2. & $\begin{array}{l}\text { Revenues from fee for training in higher and } \\
\text { secondary special, professional educational } \\
\text { institutions; }\end{array}$ & $\begin{array}{l}\text { 111-"Revenues from } \\
\text { the paid-contract form } \\
\text { of training in } \\
\text { educational } \\
\text { institutions" }\end{array}$ & $\begin{array}{l}\text { 175-“Other } \\
\text { settlements with } \\
\text { students" }\end{array}$ \\
\hline 3. & $\begin{array}{l}\text { Revenues from fee for food of the contingent } \\
\text { under treatment in inpatient medical and } \\
\text { preventive institutions }\end{array}$ & $\begin{array}{l}110 \text {-"Resources } \\
\text { received from special } \\
\text { types of payment" }\end{array}$ & $\begin{array}{l}\text { 156-"Settlements } \\
\text { for special types } \\
\text { of charges" }\end{array}$ \\
\hline
\end{tabular}

The Treasury maintains treasury personal accounts (TPA) of extra-budgetary funds of public educational and medical institutions. Based on the cash-basis method of budget 
execution, revenue related to the flow of extra-budgetary resources of institutions accounts for income in the information system for public finance management (table 3 ).

Table 3. Accounting of income from extra-budgetary resources of public educational and medical institutions in the information system for public finance management [9].

\begin{tabular}{|c|c|c|c|}
\hline \multirow{2}{*}{ № } & Transaction content & \multicolumn{2}{c|}{ Accounting Entry } \\
\cline { 3 - 4 } & \multicolumn{2}{|c|}{ Income from extra-budgetary resources of institutions } \\
\hline \multicolumn{2}{|c|}{ Credits } \\
\hline 1. & $\begin{array}{l}\text { Income from extrabudgetary resources } \\
\text { of institutions }\end{array}$ & $\begin{array}{c}\text { 019-“Extra-budgetary } \\
\text { funds of budget } \\
\text { recipients” }\end{array}$ & $\begin{array}{c}\text { 049-"Extra-budgetary } \\
\text { revenues of budget } \\
\text { recipients" }\end{array}$ \\
\hline
\end{tabular}

Current and summary information related to the accounting of income (revenues) from extra-budgetary funds in public educational and medical institutions is formed in detail. However, in the information system for public finance management, the accounting of extrabudgetary resources of institutions in connection with cash flows - the cash-basis method, prevents the formation of information about the extra-budgetary funds of budgetary institutions recorded or pending revenues, which are considered an integral part of the budget system. In other words, in the context of the development of information technologies, it is not possible to determine in what volume the income (revenues) from extra-budgetary resources are actually generated in public educational and medical institutions during the reporting period.

If we continue this research and study the accounting of expenditures on extra-budgetary funds of educational and medical institutions, we will face the above circumstances again. The expenditure of extra-budgetary funds of institutions from treasury accounts in the information system for public finance management is recorded as an expenditure (Table 4).

Table 4. Accounting of expenditures on extra budgetary funds of public educational and medical institutions in the information system of public finance management [9].

\begin{tabular}{|c|c|c|c|}
\hline \multirow{2}{*}{ № } & \multirow{2}{*}{ Transaction content } & \multicolumn{2}{|c|}{ Accounting Entry } \\
\hline & & Debits & Credits \\
\hline \multicolumn{4}{|c|}{ Expenditures on extra-budgetary funds of institutions } \\
\hline 1. & $\begin{array}{l}\text { Expenditures on extra-budgetary } \\
\text { resources of institutions }\end{array}$ & $\begin{array}{l}\text { 029-“Extrabudgetary } \\
\text { expenditures of budget } \\
\text { recipients" }\end{array}$ & $\begin{array}{l}\text { 019-"Extrabudgetary } \\
\text { funds of budget } \\
\text { recipients" }\end{array}$ \\
\hline
\end{tabular}

Accounting of expenditures on extra-budgetary resources of institutions is maintained with division into actual expenditures and cash expenditures. Expenditures taken into account in the information system for public finance management on extra-budgetary funds of institutions have the same importance as cash expenses. It means that spending extrabudgetary funds of educational and medical institutions from TPA is taken into account as cash expense in both the information system for public finance management and the information accounting system of institutions. Expenditures calculated on extra-budgetary funds are accounted as actual expenditures directly in the institution (table 5).

Table 5. Calculated costs of extra-budgetary funds of public educational and medical institutions [8].

\begin{tabular}{|l|l|c|c|}
\hline \multirow{2}{*}{$№$} & \multirow{2}{*}{ Transaction content } & \multicolumn{2}{|c|}{ Accounting Entry } \\
\cline { 3 - 4 } & & Debits & Credits \\
\hline
\end{tabular}




\begin{tabular}{|c|c|c|c|}
\hline \multicolumn{4}{|c|}{ Expenditures calculated on the basis of extrabudgetary funds of institutions } \\
\hline 1. & $\begin{array}{l}\text { Expenditures calculated on the basis } \\
\text { of the funds generated by charged } \\
\text { fees }\end{array}$ & $\begin{array}{l}\text { 241-“Actual expenditures } \\
\text { which paid from payments } \\
\text { for special types of } \\
\text { charges" }\end{array}$ & \multirow{4}{*}{$\begin{array}{l}\text { 02-"Depreciation } \\
\text { of fixed assets," } \\
\text { 06-“Other } \\
\text { inventories," } \\
\text { 15-"Payments with } \\
\text { different debtors } \\
\text { and creditors," } \\
\text { 16-"Payments with } \\
\text { budget and extra } \\
\text { budgetary funds," } \\
\text { 17-“Payments with } \\
\text { employees and } \\
\text { fellows" }\end{array}$} \\
\hline 2. & $\begin{array}{l}\text { Expenditures calculated on the basis } \\
\text { of funds received from the fee-based } \\
\text { form of education in higher and } \\
\text { secondary special, professional } \\
\text { educational institutions }\end{array}$ & $\begin{array}{l}\text { 251-"Actual expenditures } \\
\text { which paid from revenues } \\
\text { received from the paid- } \\
\text { contract form of education } \\
\text { in educational institutions" }\end{array}$ & \\
\hline 3. & $\begin{array}{l}\text { Expenditures calculated on the basis } \\
\text { of the Fund of development of } \\
\text { organization }\end{array}$ & $\begin{array}{l}\text { 261-“Actual expenditures } \\
\text { which paid from resources } \\
\text { of the Fund of development } \\
\text { of budget organization" }\end{array}$ & \\
\hline 4. & $\begin{array}{l}\text { Expenditures calculated on the basis } \\
\text { of other extra-budgetary resources }\end{array}$ & $\begin{array}{l}\text { 271-"Actual expenditures } \\
\text { by other income" }\end{array}$ & \\
\hline
\end{tabular}

Such a situation prevented the generation of current and consolidated information about expected or calculated expenditures on the basis of extra-budgetary funds of educational and medical institutions during the reporting period. This information can be generated only by summarizing the quarterly and annual reports of educational and medical institutions. It contributes to the possibility of interruptions in the extra-budgetary funds of institutions, which are covered in a single treasury account and make up almost twenty per cent of the state budget.

The formation of current and consolidated information about accounted income and expenditures of public educational and medical institutions on extra-budgetary funds in financial administration and the Treasury requires their accounting. It creates the need to improve the methodology for accounting extra-budgetary funds of institutions.

\section{Discussion}

The analysis of research on this topic was carried out with a division into two directions. The first direction is public educational and medical institutions and their financing. The second one is sources of funding of state educational and medical institutions and their accounting.

Public educational and medical institutions and their financing

In the research of the Australian scientist, G. Callender, the nature, history and role of public sector institutions were explored. He concluded that public sector institutions, through their involvement in governance linkages between government, the private sector and civil society, served as decision-makers in public administration. He developed recommendations about the role of public sector institutions in determining the efficiency indicators of public services and their impact on economic management and stimulation. [10]

According to researches of the International Institute of Internal Auditors, public sector institutions are divided into three main types. The first is regional government bodies, structural units of ministries and departments and institutions accountable to them, which the central government organizes in accordance with the established procedure. The second is agencies, which are part of the government and consist of institutions providing public services. The third type is public institutions, which carry out an activity independently of the government, produce their products, provide services, and have their sources of income. [11] These levels are recommended for consideration in funding and monitoring public sector institutions.

According to an International Monetary Fund report dated April 2020, government spending in developed countries is about 40 per cent of GDP, emphasizing that public education and health institutions are the largest employers. It was noted that in the context of 
the pandemic and crisis, financing of public educational and medical institutions ensures social and economic stability. [12]

The above research highlights the role of public educational and medical institutions in the life of the state and society and the features of their financing. Also, the need for extrabudgetary financing through the provision of paid services and production is shown in addition to budgetary financing of public educational and medical institutions.

In the study of funding sources of public educational and medical institutions and their accounting, ensuring transparency of information is an important direction in the effective use of funds. In particular, the reports of the International Association of Chartered Certified Accountants (ACCA) noted that strong financial management in the using of resources in the public sector, accountability for spending and transparency of information would serve fiscal sustainability, correct distribution and effective management of funds, as well as increase the economic efficiency of public services. [13]

Dr Jens Heiling, an expert at the international audit organization ERNST \& YOUNG, noted that the unprecedented actions that governments worldwide take during the COVID19 pandemic have demonstrated how important public education and medical institutions to society and the economy. Also, it is emphasized that ensuring the transparency and reliability of accounting information and financial reporting in educational and medical institutions plays a decisive role. In ensuring targeted use of funds in the public sector, the importance of public sector accounting was demonstrated by the experience of Greece and Portugal. [14]

The World Bank research concluded that accountability, transparency, planning and monitoring are essential at budget execution in different countries and funding public educational and medical institutions. It is also recommended to ensure the completeness and transparency of budget performance information by taking into account extra-budgetary funds from educational and medical institutions and covering information about their movement. [15]

It was noted in these studies that in financing public educational and medical institutions, maintaining a single accounting of not only budget resources but also extra-budgetary revenues and their expenditure, the formation of systematic information on them will serve to ensure transparency of data on budget performance and publicity of the financial activities of public educational and medical institutions.

\section{Conclusion}

The above analysis and observations show how extra budgetary resources of public sector institutions and their accounting are important for the budget system. Reforms of the budget system require realizing the following tasks related to improve the methodology of accounting extra-budgetary resources of public sector institutions:

1. It is necessary to establish the procedure for the transfer of extra-budgetary resources of public educational and medical institutions, which are not used during the financial year for the purposes set before the beginning of the next financial year, without redistributing them for the next year when estimates to be prepared. Thus, public educational and medical institutions will ensure the using extra-budgetary resources during the financial year for the purposes provided in the estimates of income and expenditures. It will also ensure timely implementation settlement and non-excess accounts payable in public educational and medical institutions during the financing of expenditures related to extra-budgetary resources.

2. When it is possible to cover the expenditures incurred within the approved estimates for extra-budgetary funds of public educational and medical institutions with revenues expected to be received, it is necessary to establish a permit to increase relative to the approved amounts. As a result, public educational and medical institutions will be able to 
increase extra-budgetary expenditures within the sources of their coverage, implement and calculate in a short time their expenditures for activity. The possibility of public educational and medical institutions to order and manage extra-budgetary resources will be further expanded.

3. It is necessary to implement accounting in financial administration and treasury offices through single accounts for income of public sector institutions calculated based on extrabudgetary resources. As a result, current and consolidated information about the types of income from extra-budgetary funds of public educational and medical institutions covered by the treasury execution system will be generated in financial administration and treasury departments. It will also ensure the generation of information about expected income from extra-budgetary funds of public educational and medical institutions in the relevant financial administration and the treasury system as a whole. Information about treasury performance of budget system income will be aligned with a modified (mixed) method based on international accounting standards for the public sector.

4. It is necessary to implement the accounting of calculated expenditures based on extrabudgetary resources of public sector institutions by using single personal accounts in financial administration and treasury offices. Keeping records of expenditures on extrabudgetary funds of public educational and medical institutions in institutional and financial administration and treasury departments contributes to the formation of operational accounting information about expected current financial commitments for these types of funds. As a result, it will be possible to analyze information about current financial commitments and estimated actual expenditures of public educational and medical institutions related to extra-budgetary funds, as well as effective management of resources.

\section{References}

1. Budget for citizens 2021 (Tashkent, 2020)

2. President of the Republic of Uzbekistan Shavkat Mirziyoyev's Address to the Oliy Majlis (2020)

3. Budget Code of the Republic of Uzbekistan, 360 (2013)

4. Cabinet of Ministers Resolution (2018)

5. Cabinet of Ministers Resolution (2018)

6. Regulation (2019)

7. Regulation (2019)

8. Instruction, 69 (2010)

9. Order of the Minister of Finance of the Republic of Uzbekistan 157 (2019)

10. G. Callender, International Encyclopedia of the Social \& Behavioral Sciences., 56 (2001)

11. The Institute of Internal Auditors Supplemental Guidance: Public Sector Definition, 8 (2011)

12. International Monetary Fund Fiscal Monitor: Policies to Support People During the COVID-19 Pandemic, 14 (2020)

13. The Association of Chartered Certified Accountants Improving public sector financial management in developing countries and emerging economies, 2 (2010) https://www.accaglobal.com 
14. Dr. Jens Heiling, Contributing to The Global Economy. Public Sector Accounting - A Discipline in Its Own Right. ERNST \& YOUNG GMBH, Stuttgart, Germany (2020) https://www.ifac.org

15. Anwar Shah, The World Bank. 93 (2018) https://www.researchgate.net 